Int. J. Dev. Biol. 52: 1105-1111 (2008)

doi: $10.1387 / \mathrm{ijdb} .072284 \mathrm{mb}$

\title{
Imprinting of mammalian male gametes is gene specific and does not occur at a single stage of differentiation
}

\author{
MARÍA D. BOYANO*, NOELIA ANDOLLO, MARÍA M. ZALDUENDO and JUAN ARÉCHAGA \\ Laboratory of Developmental Biology \& Cancer. Department of Cell Biology and Histology, Faculty of Medicine and Dentistry, \\ University of the Basque Country, Leioa, Vizcaya, Spain
}

\begin{abstract}
Epigenetic modifications such as DNA methylation and alterations to chromatin structure have been proposed as hallmarks of imprinting in somatic cells after fertilization. In the germ cell line, gene imprinting needs to be reset in order to transmit the correct sex-specific imprinting pattern to the next generation. The precise timing of imprint erasure and re-establishment for many genes remains to be determined and precise molecular mechanisms of genomic imprinting have not yet been fully characterized. Here, we have analysed the methylation state and DNase-I sensitivity of two genes with reciprocal genomic imprinting (U2af1-rs1 and H19 genes) in a male mouse primordial germ cell (PGC) derived cell line (EG-1), isolated post-natal spermatogonia and mature sperm cells. Our results show that establishment of imprinting of the U2af1-rs 1 and $H 19$ genes during male germ cell differentiation occurs at different stages of differentiation. Furthermore, the presence of DNase-I hypersensitive sites may constitute a molecular marker to identify alleles and subsequently acquire the appropriate methylation imprint. We propose that this molecular identifier may be present or absent for a specific gene according to the sex of the gamete.
\end{abstract}

KEY WORDS: DNA methylation, DNase-I hypersensitive site, U2af1-rs1 gene, H19 gene, germ cell

\section{Introduction}

Mammalian development requires genetic information from both parents. However, in diploid organisms, expression of genes from both alleles does not always occur. Genes in which monoallelic expression is governed by the parental origin of the allele are termed imprinted genes and the epigenetic mechanism which gives rise to their monoallelic expression is known as genomic imprinting (Reik and Walter, 2001a; Ferguson-Smith et al., 2001; da Rocha and Ferguson-Smith, 2004; Peters and Beechey, 2004; Murrell, 2006).

The U2af1-rs1 gene is a small intronless gene, located in the proximal region of mouse chromosome 11, which encodes a protein that shares homology with the U2 small nuclear ribonucleoprotein auxiliary factor (Hatada et al., 1993; Hayashizaki et al., 1994). The maternal allele of this gene is imprinted and it is the paternal allele which is expressed in embryonic and adult tissues (Shibata et al., 1996; Feil et al., 1997; Zhang et al., 2006).

The H19 gene is mapped to a cluster of imprinted genes located in the distal region of mouse chromosome 7 . It encodes the RNA of the most abundant ribonucleoprotein particle found during embryo development (Brannan et al., 1990; Pachnis et al.,
1998). In contrast to the U2af1-rs1gene, the imprinted allele is the paternal one and expression of this gene takes place from the maternal allele. It is thought that $H 19$ participates in downregulating cellular proliferation (Bartolomei and Tilghman, 1997).

Chromatin structure of most imprinted genes presents differences between the maternal and paternal alleles (Feil et al., 1995). Differentially methylated regions (DMRs), which are CpG rich areas subjected to epigenetic modifications (Constancia et al., 1998; Tilghman, 1999), also present allele-specific differences (Tada et al., 1998; Jaenisch and Bird, 2003; Durcova-Hills et al., 2004). Moreover, the role of regulatory elements at imprinted domains (Thorvaldsennet al., 2002; Arney, 2003; Arney and Fisher, 2004; Delaval and Feil, 2004) and other processes such as acetylation and methylation of histones, and chromatin dynamics (Turner, 2000; Gregory etal., 2002; Drewell et al., 2002; Delaval et al., 2007; Hajkova et al., 2008) may be equally important for imprinting. In the initial stages of development, these processes are necessary to correct embryo differentiation. Pa-

Abbreviations used in this paper: DMR, differentially methylated region; HSS, hypersensitive sites; PGC, primordial germ cell.

\footnotetext{
*Address correspondence to: María D. Boyano. Department of Cell Biology and Histology, Faculty of Medicine and Dentistry, University of the Basque Country, E-48940 Leioa, Vizcaya, Spain. Tel: +34-94-601-5689. Fax: +34-94-601-3266. e-mail: Iola.boyano@ehu.es
} 
rental imprinting is conserved in all somatic cells of the embryo but in germ cells, this imprint must be erased and a new sex-specific imprint which will be inherited by the next generation must be reestablished. Successful erasure and re-establishment of sexspecific epigenetic marks in primordial and post-natal germ cells are crucial for normal development. It has been suggested that each gene has a specific time window to receive primary imprinting (Obata and Kono, 2002), but gene-specific information about the timing of imprinting is lacking. Moreover, the molecular mechanisms underlying genomic imprinting have not yet been fully characterized.

In order to address these questions, we have analyzed the methylation pattern and chromatin structure of the U2af1-rs1 and H19 imprinted genes in a mouse male PGC derived cell line (EG1), isolated spermatogonia from 6-7 day old mouse testes and mature sperm cells. Our data indicate that re-establishment of genomic imprinting of the U2af1-rs 1 and H19 genes during male germ differentiation occurs at different stages of development. Furthermore, the presence of DNase-I hypersensitive sites may constitute a molecular marker to identify the future maternal or paternal alleles and subsequently acquire the appropriate methylation imprint.

\section{Results}

\section{Methylation patterns of the U2af1-rs1 and $\mathrm{H} 19$ genes}

In this study we have examined spermatogonia and somatic cells obtained from 6-7 day-old mouse testes, mature sperm cells and the MSC-1 Sertoli cell line. By flow cytometry we found that spermatogonia cells were SSEA-1 and vimentin negative, while freshly isolated Sertoli cells and the MSC-1 cell line were SSEA1 negative and vimentin positive. The purity of each population obtained was always superior to $90 \%$. We analyzed the isolated spermatogonia (Fig. 1 A, B) and Sertoli cells (Fig. 1 C) by electron microscopy. The prevailing spermatogenic cells detectable in the former cell population were primitive ( $p$ ) and type $A(a)$ spermatogonia (Bellvé et al., 1977).

For methylation analysis of the U2af1-rs1gene, we studied its DMR, which includes the gene and its flanking sequences (Fig. $2 \mathrm{~A})$. To isolate this region, we digested DNA with the $\mathrm{Bg} / \mathrm{II}$ restriction enzyme, generating a $5.8 \mathrm{~kb}$ fragment. Then, we analyzed the methylation dependent Not I and Hpa II restriction sites in this region. For spermatogonia, DNA was found to be partially methylated (Fig. 2 B, lanes 1-3) indicating that imprint establishment had not yet happened at this stage of male germ cell differentiation. Since the U2af1-rs1gene is methylated only in its maternal allele, it was expected that both alleles would progressively reach a demethylated state. However, we observed increased levels of methylation in more differentiated male germ cells (Fig. 2C, lanes 1-3). Thus, 30\% of the Not I and Hpa II restriction sites in the U2af1-rs1 DMR from spermatogonia cells were found to be methylated (Fig. 2B), while in mature sperm cells the level of methylation was found to be $50 \%$ and $40 \%$ at Not and Hpa II restriction sequences, respectively (Fig. 2 C). In the case of isolated Sertoli cells and the MSC-1 Sertoli cell line used as control somatic cells, approximately $50 \%$ of the alleles were found to be methylated (Fig. $2 \mathrm{D}, \mathrm{E}$ ).

The frequently studied $H 19$ DMR located 2-4 kb upstream of the $H 19$ coding sequence is delimited by Sac I restriction sites (Fig. 3A). Another small region situated upstream near the promoter presents a differential pattern of methylation in alleles according to their parental origin (Davis et al., 1999). Thus, in the present study we also employed the BstX I enzyme, which generates a restriction fragment including both of these DMRs. We analyzed restriction sequences of the methylation dependent Hhal enzyme in these two regions.

Partial methylation of Hha I restriction sites was observed in the BstXI region of spermatogonia, sperm cells, isolated Sertoli cells and MSC-1 Sertoli cells (Fig. 3 B, C, D and E, respectively, lanes 2). In spermatogonia, the $5.3 \mathrm{~kb}$ band obtained after DNA digestion with BstXI and Hhal enzymes was approximately $30 \%$ of that found after DNA digestion with BstXI alone (Fig. $3 \mathrm{~B}$, line 2). However, in mature sperm cells, the level of methylation at the Bst XI fragment was observed to be twofold (60\%) (Fig. $3 \mathrm{C}$, lane 2). The methylation level detected in the Sacl limited DMR of the H19 gene in spermatogonia (60\%, Fig. $3 \mathrm{~B}$, lane 3 ) was found to be much higher than in somatic cells $(40 \%$ and $30 \%$ in isolated Sertoli and MSC-1 cells, respectively; Fig. 3 D and E, lanes 3). Finally, in mature sperm cells, $75 \%$ of completely methylated Hha I restriction sequences were observed at this region (Fig. $3 \mathrm{C}$, lane 3).

\section{Chromatin structure of the U2af1-rs1 and $\mathrm{H} 19$ genes}

To analyze possible modifications in chromatin structure of
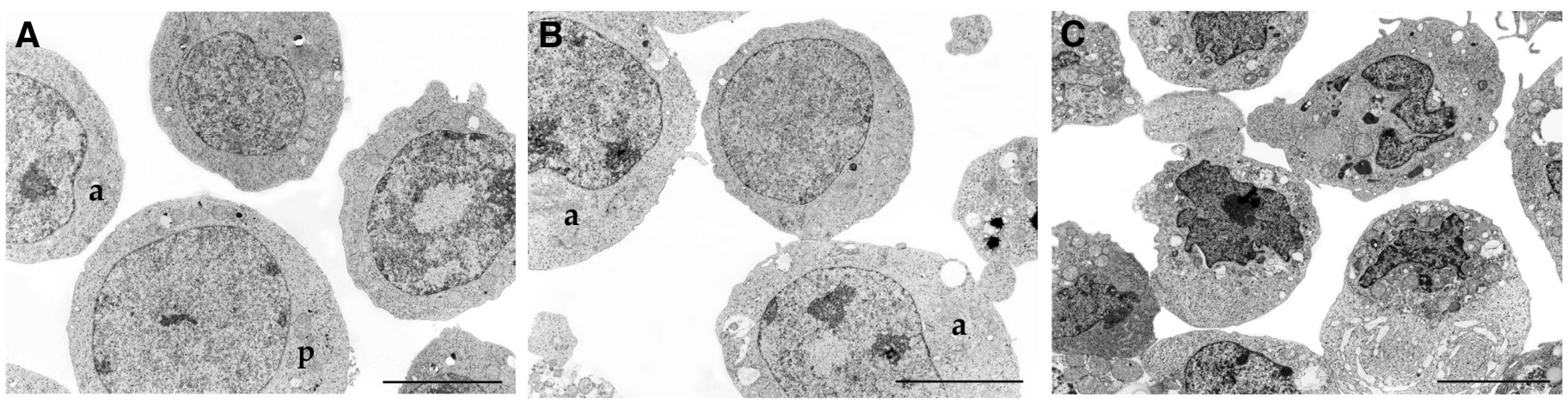

Fig. 1. Morphology of spermatogonia and isolated Sertoli cells. Transmission electron micrographs showing morphological characteristics of spermatogonia $(\mathbf{A}, \mathbf{B})$ and isolated Sertoli cells $\mathbf{( C )}$ obtained from 6-7 day-old mice testes. Following the morphological and structural standard described by Bellvé et al. (1977), the prevailing spermatogenic cells detectable at this stage of germ cell development were primitive (p) and type $A$ (a) spermatogonia. Scale bar, $5 \mu \mathrm{m}$. 
A

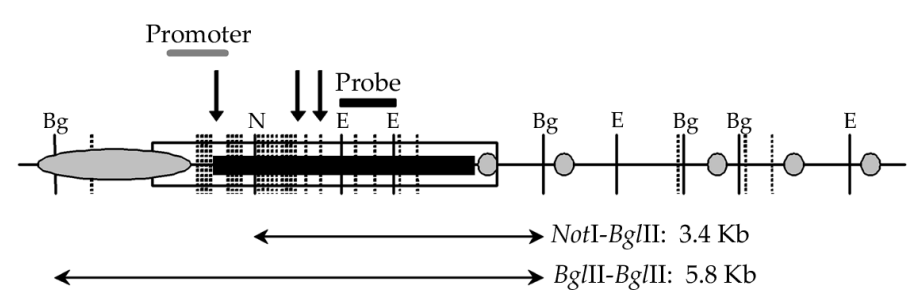

B

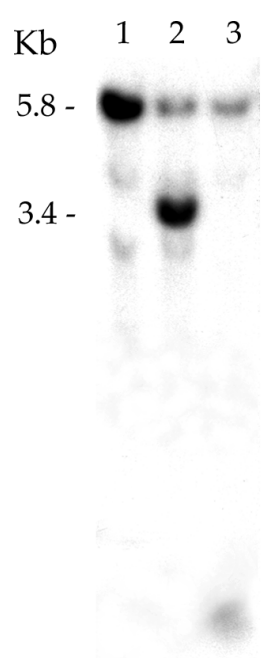

C

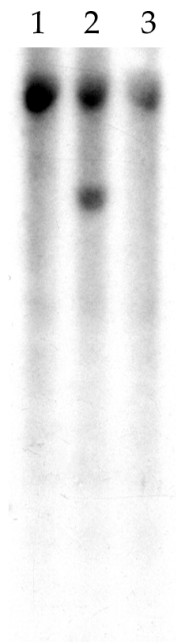

D

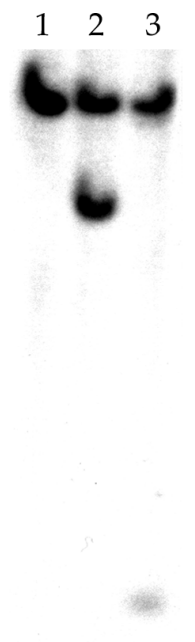

E 123
A

$H 19$

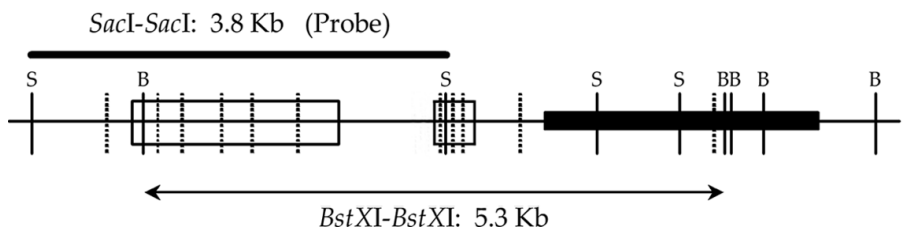

B

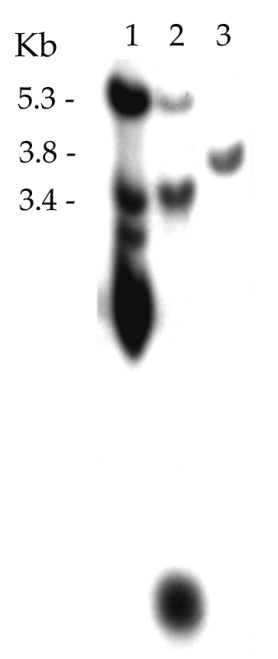

C

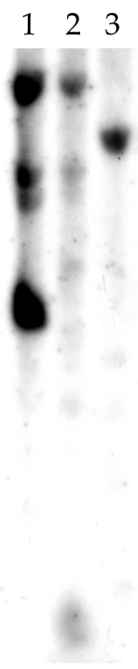

D

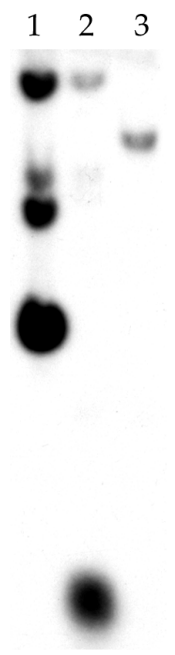

$\mathbf{E}$

123

Fig. 2 (Left). Methylation pattern of the U2af1-rs1 gene. (A) The U2af1-rs1 gene (black box) and flanking sequences (GenBank accession number AF309654) include the EcoR/ (E), Bgl/I (Bg), Not / (N) and Hpall (disrupted lines) restriction sites. A 630 base pair EcoR/ fragment was used as a probe. The open rectangle denotes the position of the differentially methylated region (DMR) and the grey rounded figures indicate the location of repetitive sequences. The thick line above the gene represents the promoter. The size of the restriction fragments obtained following digestion with Bgl// or $\mathrm{Bgl} / \mathrm{l}+$ Not/ restriction enzymes is also shown. DNase-l hypersensitive sites (vertical arrows) are located in a broad region within approximately $1 \mathrm{~Kb}$ from the U2af1-rs1 transcription start site. The DNA methylation pattern was analyzed by Southern blotting in spermatogonia (B), mature sperm cells (C), control isolated Sertoli cells (D) and in the MSC-1 Sertolicell line (E). To perform methylation assays, samples were incubated with Bgl/I, Bgl/I+Not/ and $\mathrm{Bg} / / \mathrm{H}+\mathrm{Hpa} / \mathrm{l}$ restriction enzymes (lanes 1, 2 and 3 respectively).

Fig. 3 (Right). Methylation pattern of the $\mathbf{H 1 9}$ gene. (A) The H19 gene (black box) and its upstream sequence (GenBank accession number U19619) include the BstXI (Bs), Sacl (S) and Hhal (disrupted lines) restriction sites. A 3.8 kbSac/ DNA fragment was used as a probe. The DMRs (open rectangles) are located at -2 to $-4 \mathrm{~kb}$ and less than $1 \mathrm{~kb}$ upstream from the transcription start site. The BstXI restriction fragment is also shown. The DNA methylation pattern was analyzed by Southern blotting in spermatogonia (B), mature sperm cells (C), control isolated Sertoli cells (D) and in the MSC-1 Sertoli cell line (E). To perform methylation assays, samples were incubated with BstXI, BstXI+Hhal and Sacl+Hhal restriction enzymes (lanes 1 , 2 and 3 respectively).

alleles during the process of establishment of the parental imprint, we performed DNase-I sensitivity assays. Samples of isolated nuclei from each cell type were treated with increasing concentrations of DNase-I endonuclease and afterwards with $B g / I I$ or SaC I restriction enzymes, depending on the studied U2af1-rs1 or H19 gene, respectively. Densitometric analysis revealed that postnatal spermatogonia showed higher sensitivity to DNase-I digestion than isolated Sertoli cells or MSC-1 Sertoli cell line in the analized region of both genes (Figs. 4 and $5 A, B, C$ ).

Then, we analyzed hypersensitive sites (HSS). For the U2af1rs1 gene, we detected these sites in spermatogonia as well as in isolated Sertoli cells and in the MSC-1 Sertoli cell line (Fig. 4 A, B and $C$ ). Consequently, we decided to study the presence of HSS in male EG-1 and female EG-3 embryonic germ cells, which derive from $8.5 \mathrm{dpc}$ mouse embryo PGCs. HSS were found to be present in the analyzed region in male EG-1 embryonic germ cells. In contrast, no HSS were detected in the EG-3 female embryonic germ cell line (Fig. $4 \mathrm{D}$ and E). Thus, we detected HSS in all the male germ cells examined, but not in female germ cells. These HSS were located in a broad region at approximately $1 \mathrm{~kb}$ downstream from the transcription start site of U2af1-rs1. The approximately $4 \mathrm{~Kb}$ band detected in all samples is likely a digestion product due to the activity of endogenous nucleases present during nuclear isolation. This fragment is located in the promoter region of the U2af1-rs1 gene.

For the H19 gene, several HSS were detected in all cell types analyzed at the DMR located 2-4 kb upstream, except in spermatogonia (Fig. 5 A, B, C, D and E). Moreover, a close chromatin 
conformation was detected in EG-1 male embryonic germ cells in comparison to that of EG3 female cells (Fig. 5 D and E).

\section{Discussion}

DNA methylation is one of the most relevant mechanisms which participates in the control of genomic imprinting. In somatic cells, imprinted genes can be identified as those which present DMR methylation in $50 \%$ of their alleles. This percentage corresponds to the maternal alleles in the case of the U2af1-rs1gene or the paternal ones in the case of the $H 19$ imprinted gene. So, a state of complete demethylation for the U2af1-rs1gene or complete methylation for the $H 19$ gene is likely to be indicative of establishment of genomic imprinting.

We found that the Not I and Hpa II restriction sites in the U2af1-rs1DMR were partially methylated in spermatogonia and sperm cells. Surprisingly, we detected a level of methylation which increased with the development of the male germ cell line. Thus, sperm cells presented complete methylation of the Not I and Hpa II restriction sites in approximately half of the U2af1-rs1 alleles. These results indicate that the imprinting of the U2af1-rs1 gene is not totally established in sperm cells.

Previous reports support the idea that the allelic methylation pattern is not fully established in the gametes, but will be complete after fertilization or even during the initial stages of embryo development (Brandeis et al., 1993; El-Maarri, 2001; Reik and Walter, 2001b; Jeong et al., 2007; Polanski et al., 2008). Moreover, using a sensitive immunofluorescence assay with a wellcharacterized antibody to 5-methyl cytosine, it has been shown that after fertilization and prior to the first DNA duplication, the paternal genome is selectively demethylated while the maternal genome displays de novomethylation (Mayer etal., 2000; Oswald et al., 2000). This active demethylation process occurs immediately following sperm decondensation and by 4 hours postfertilization maternal and paternal genomes are unequally methylated (Santos et al., 2002).

Concerning the methylation status of the $H 19$ gene, we found a progressive increment at the Hha I sites in Sacl and BstXI fragments for spermatogonia and sperm cells, although methylation was not absolute. Results from other authors that have analysed restriction sites in this gene are compatible with our findings, showing that methylation at Hha I restriction sites is incomplete, despite the fact that new genomic imprinting has been established (Ueda et al., 2000). In fact, the detected methylation was approximately twofold in the Sac I DMR of the H19 gene in spermatogonia and sperm cells with respect to somatic cells, suggesting that all $H 19$ alleles are methylated in spermatogonia and gametes. The Bst $X I$ fragment presented a similar level of methylation in both spermatogonia and somatic cells, but this degree of methylation was increased almost twofold in sperm cells. Therefore, in contrast to the U2af1-rs1 gene, imprinting of
B

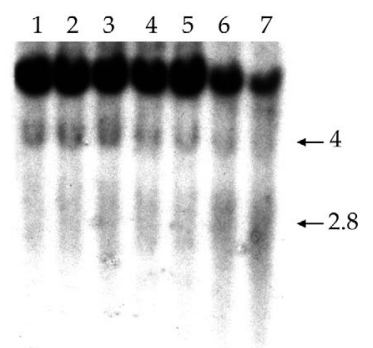

C

$\begin{array}{lllllll}1 & 2 & 3 & 4 & 5 & 6 & 7\end{array}$

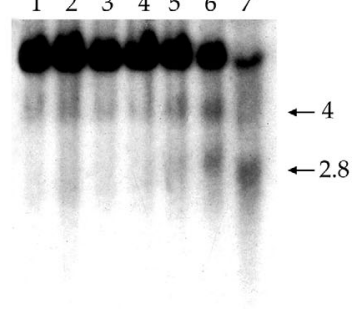

E.

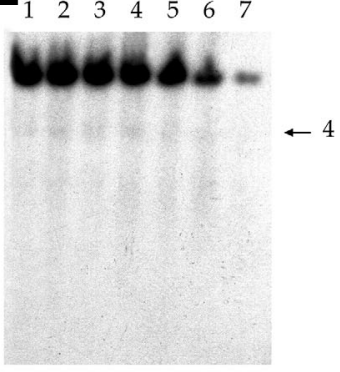

$-4$

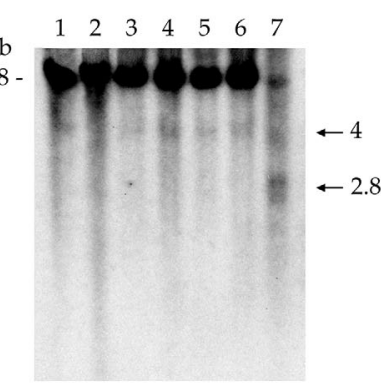

Fig. 4. DNase-I sensitivity of the U2af1-rs1 gene. DNase-l sensitivity was analyzed by Southern blotting of spermatogonia (A), control isolated Sertoli cells (B), MSC-1 Sertoli cell line and of male EG-1 (D) and female EG-3 (E) embryonic germ cell lines. For nuclease sensitivity (llanes -7), DNA was isolated from nuclei and digested with BgIII. Arrows indicate DNase-l digestion products corresponding to hypersensitive sites.

H19appears to be completely established in the male gametes.

It is noteworthy that methylation of the Sac I DMR was observed during the spermatogonia stage, whereas methylation of the $B s t X I$ restriction fragment, which includes the promoter and the 5'-extreme of the H19 gene, was observed later, during the sperm cell stage of differentiation. Thus, the occurrence of methylation of the BstX I fragment subsequent to that of the Sac I fragment during the course of development corroborates the theory that proximal promoter region is probably involved in the maintenance rather than the establishment of $H 19$ genomic imprinting (Davis et al., 1999; Davis et al., 2000).

Prior to the establishment of methylation, other epigenetic mechanisms may be involved to determine the identification of alleles as future paternal or maternal and subsequently permit the selective methylation of the appropriate maternal or paternal allele of the imprinted gene. Thus, the present results point to the possibility that modifications in chromatin structure and more specifically the presence of DNase-I hypersensitive sites (HSS), may be involved in the sex-specific labelling of alleles.

In the present work, we have detected HSS for the U2af1-rs1 gene in male germ and somatic cells, but not in female germ cells, which only contain future maternal alleles and will become methylated. These findings suggest the association of HSS with the U2af1-rs 1 paternal allele. It is possible that the presence of HSS may be related to the joining of specific DNA binding proteins involved in keeping the paternal allele unmethylated, as has been described previously by Feil and Khosla (1999).

At the H19 DMR, we detected several HSS in the different types of cellular nuclei analyzed, with the exception of nuclei of 


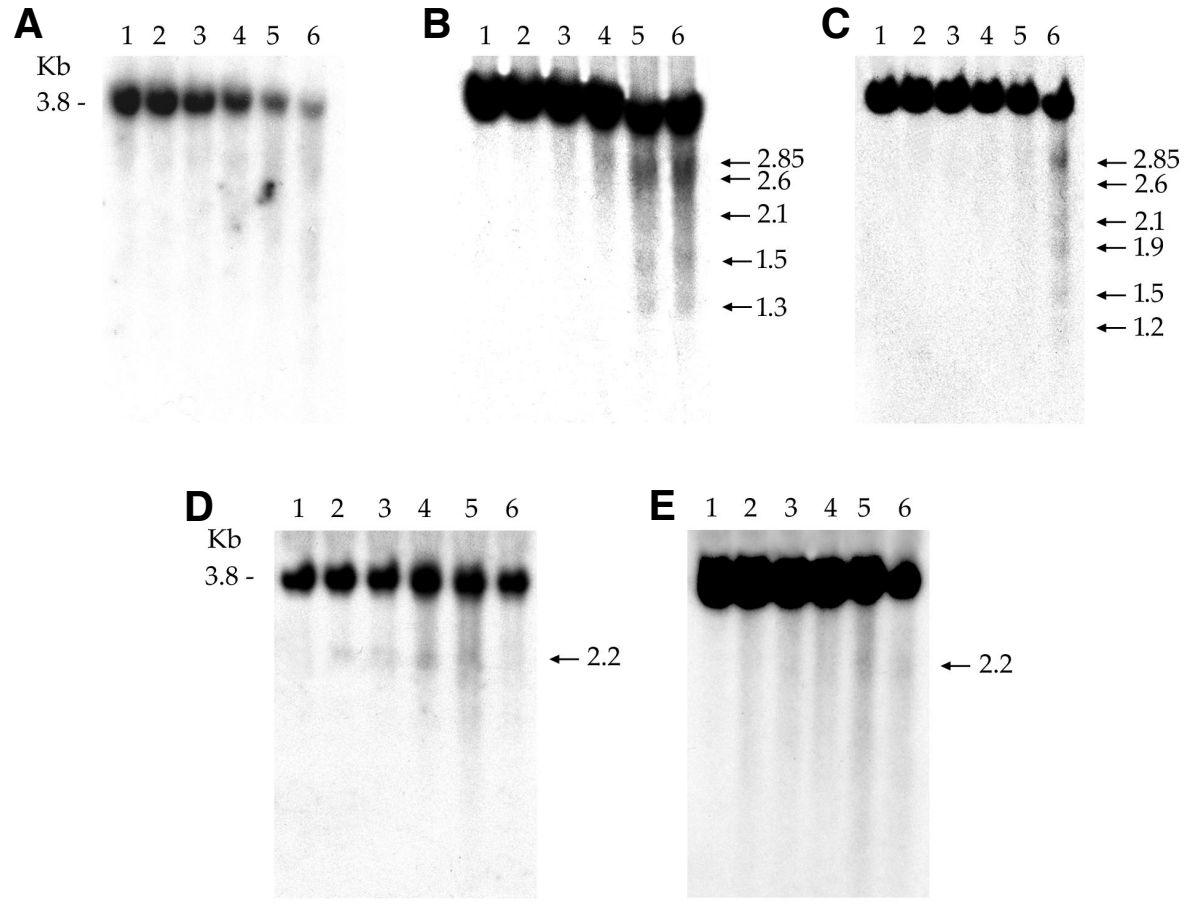

Fig. 5. DNase-I sensitivity of the $\boldsymbol{H} 19$ gene. DNase-l sensitivity was analyzed by Southern blotting of spermatogonia (A), control isolated Sertoli cells (B), MSC-1 Sertoli cell line (C) and of male EG-1 (D) and female EG-3 (E) embryonic germ cell lines. For nuclease sensitivity analysis, after incubation of nuclei with 0, 10, 20, 40, 80 and $160 \mathrm{U} / \mathrm{ml}$ of DNase-I (lanes 1-6), DNA was extracted from nuclei and digested with Sacl. Arrows indicate DNase-l digestion products corresponding to hypersensitive sites.

spermatogonia. Since the spermatogonia will produce male gametes, in which the $H 19$ gene must be methylated, it is conceivable that the absence of HSS allows these alleles to acquire methylation imprinting. Consequently, the HSS detected in female EG-3 embryonic germ cells as well as in somatic cells would be associated with maternal alleles. HSS in EG-1 embryonic germ cell line (derived from 8,5 dpc mouse embryo PGCs) may be due to the fact that erasure of imprinting of the $H 19$ gene has not yet happened at this stage of development (Hajkova et al., 2002; Li et al., 2004; Trasler, 2006). Consistently, other authors have detected HSS in maternal alleles of somatic cells from several tissues with and without gene expression (Hark and Tilghman, 1998; Khosla et al., 1999), suggesting that the presence of HSS might be constitutively associated with $\mathrm{H19}$ maternal alleles.

In summary, our results suggest that the establishment of imprinting in the male germ cell line is gene specific and that this process does not occur during a single stage of development. Moreover, the presence of DNase-I hypersensitive sites (HSS) may constitute a molecular marker to identify alleles and subsequently acquire the appropriate methylation imprint. Thus, this identifier would be present or absent for a specific gene according to the sex of the gamete.

\section{Materials and Methods}

\section{Animals and cell lines}

Pathogen-free C57BL/6 $\left(\mathrm{H}-2^{\mathrm{b}}\right)$ mice were purchased from Iffa Credo Laboratories (France). Sertoli MSC-1 cell line were cultured with DMEM supplemented with $10 \%$ fetal bovine serum, $32 \mathrm{mM} \mathrm{NaHCO}_{3}, 2 \mathrm{mM}$ glutamine, $100 \mathrm{U} / \mathrm{ml}$ penicillin and $100 \mu \mathrm{g} / \mathrm{ml}$ streptomycin. Embryonic germ cell lines EG-1 and EG3 (Stewart et al., 1994) were grown on a feeder layer of freshly obtained primary mouse embryonic fibroblasts (MEF) inactivated with mitomycin C, in gelatine-coated culture flasks. Fibroblasts were collected from 12.5 days post-coitum (dpc) mouse embryos as described by Abbondanzo et al., 1993. Culture medium consisted of Dulbecco's Modified Eagle's Medium (DMEM) (Gibco, Grand Island, NY) supplemented with $15 \%$ fetal bovine serum, 32 $\mathrm{mM} \mathrm{NaHCO}, 2 \mathrm{mM}$ glutamine, $1 \%$ non-essential amino acids, $1 \mathrm{mM}$ sodium pyruvate, $50 \mathrm{mM} 2-\beta$ mercaptoethanol, $100 \mathrm{U} / \mathrm{ml}$ penicillin, $100 \mu \mathrm{g} / \mathrm{ml}$ streptomycin, $10 \mathrm{ng} / \mathrm{ml}$ Steel Factor (SF) and 20 $\mathrm{ng} / \mathrm{ml}$ leukemia inhibitory factor (LIF). EG cells were collected after 5-6 passages and the undifferentiated state of cells was tested routinely by the detection of endogenous alkaline phosphatase activity using the Red Alkaline Phosphatase Substrate Kit I (Vector, Burlingame, CA, USA).

Isolation of spermatogonia and sperm cells

Spermatogonia from 6-7 day-old mice were obtained after decapsulation of testes and digestion with collagenase-II followed by centrifugation at $85 \mathrm{~g}$ for $7 \mathrm{~min}$. Testicular cords were digested with a trypsin-EDTA salt solution and DNase-I. Cell suspension obtained was filtered throughout a nylon cell strainer (Falcon-BD Biosciences Discovery Labware Europe, Oxford, UK) to remove cell aggregates and was centrifuged at $390 \mathrm{~g}$ during $10 \mathrm{~min}$. In order to separate spermatogonia from somatic cells, cell suspensions were plated onto culture flasks and maintained at $32^{\circ} \mathrm{C}$ overnight in the same culture medium as for MSC-1 cell line. Spermatogonia remain in suspension and adherent somatic cells were collected separately, washed and used for other experimental assays. Purity of isolated spermatogonia and testicular somatic cells (mainly Sertoli cells) were analysed by electron microscope and by flow cytometry. Samples for electron microscopy observations were prepared as described previously (Andollo et al., 2005) and ultrathin sections were examined in a Philips EM208S electron microscope (Philips Electronic Instruments, Eindhoven, Netherlands). Flow cytometric analysis was performed to characterize the cell populations obtained from testis. Briefly, cells were washed in PBS and fixed in ethanol. After three washes, $1 \times 10^{6}$ cells per sample were incubated with the first antibody $\left(60 \mathrm{~min}\right.$ at $\left.37^{\circ} \mathrm{C}\right)$ in PBS containing $0.5 \%$ Bovine serum albumina (BSA, Sigma) and $0.1 \%$ sodium azide (Sigma). The following $m A b$ were used: anti-SSEA1 (Sigma) at 1:5 dilution and anti-vimentin (Roche) at 1:5 dilution. After three washes in PBS-1\% BSA-0.02\% sodium azide, cells were incubated with FITC-conjugated anti-rat IgG (1:100 dilution) (Sigma) for 30 $\min$ at $37^{\circ} \mathrm{C}$. Then cells were washed again and the percentage of positive cells was measured using a Coulter EPICS ELITE ESP flow cytometer.

Mature sperm cells were obtained from the epididymis and vas deferens from 12-16 week-old mice. Spermatozoa from the lumen of the vas deferens were collected in PBS by gently sliding smooth forceps along the length of the duct. Sperm cells of the cauda epididymis were recovered cutting the duct into $1 \mathrm{~mm}^{3}$ segments and placing the fragments in PBS. Cell and tissue preparations were vortexed briefly. Clumps of tissue were allowed to settle at unit gravity and sperm cells in the supernatants were collected. Cell suspensions were filtered through a nylon cell strainer (Falcon, Becton-Dickinson Laboratories, Orangeburg, NY, USA) to remove residual clumps of somatic 
cells. Sperm cells were recovered by centrifugation without contamination of somatic cells.

\section{Methylation analysis, nuclease sensitivity assays and Southern blotting}

Methods for methylation analysis, nuclease sensitivity assays and Southern blotting were previously described in Andollo et al., 2005. For methylation assays, cells were collected and lysed and DNA was isolated. DNA samples for the U2af1-rs1 analysis were digested with $B g / I I$ alone or in combination with Not I and Hpall methylation dependent restriction enzymes. To study the methylation status of the $\mathrm{H} 19$ gene, we analyzed the restriction sequences of the methylation dependent Hha I endonuclease in two coupled regions that are limited by the BstXl and Sacl target sites respectively. All restriction enzymes used were provided by Amersham Bioscience (Piscataway, NJ, USA). For nuclease sensitivity assays, nuclei were obtained as described in Feil et al., 1995 and assays were performed as it is said in this publication. Isolated DNAs were incubated with $B g / I$ enzyme for the U2af1-rs1 study and with SaC I enzyme for the $H 19$ analysis. Southern hybridization was carried out as previously described (Andollo et al., 2005) using a 550 base pair ECoRI fragment of U2af1-rs1 gene (probe 1), a $3.8 \mathrm{~kb}$ Sac I fragment which comprises the core region of the H19upstream region (probe H19-4) and a $1.8 \mathrm{~kb}$ human $\beta-A C T I N$ control probe (Clontech Labs, Palo Alto, CA, USA). Densitometric measurements were performed with a video-densitometer (Model 620, Bio-Rad Laboratories Ltd) using a Bio-Rad computer-assisted system (FingerPrinting 1.9). Autoradiogram band intensities for DNase-I digestions were always refereed to the value corresponding to the incubation with 0 units of nuclease. Southern blotting for individual genes was repeated three times.

\section{Acknowledgments}

We thank Dr. R. Feil for the kind gift of the $\mathrm{H} 19-4$ and probe 1 probes and for his valuable advice and critical reading of the manuscript. To Dr. C.L. Stewart and Dr. J.L. Millán are acknowledged for providing the EG and the MSC-1 cell lines, respectively. The authors would like to express thanks to the collaboration of the General Service of Analytical and High Resolution Microscopy in Biomedicine of the University of the Basque Country UPVIEHU. This work was supported in part by grants from the Basque Government (P/97/43), the University of the Basque Country (075.327-G13/99 and 9/UPV 00077.327-15304/2003) and the Spanish Ministry of Education and Science (BFU2007-66610). N.A. and M.M.Z. were supported by fellowships from the Spanish Ministry for Education and Science and the Basque Government, respectively and additionally N.A. was later awarded with a postdoctoral research fellowship from the Fundación Jesús de Gangoiti.

\section{References}

ABBONDANZO, S.J., GADI, I., STEWARD C.L. (1993) Derivation of embryonic stem cell lines. In Guide to Techniques in mouse development. Wassarman P.M. and DePamphilis M.L. Eds. Methods in Enzymology, Vol.225, pp 803-823. Academic Press.

ANDOLLO, N., BOYANO, M. D., ANDRADE, R., ZALDUENDO, M. M., EGUIZABAL, C., ASUMENDI, A., ARLUCEA, J. and ARÉCHAGA, J. (2005) Structural and functional preservation of specific sequences of DNA and mRNA in apoptotic bodies from ES cells. Apoptosis 10: 417-428.

ARNEY, K.L. (2003) H19and /gf2-enhancing the confusion? Trends Genet19:1723.

ARNEY, K.L. and FISHER, A.G. (2004) Epigenetic aspects of differentiation. J Cell Sci117:4355-63.

BARTOLOMEI, M.S. and TILGHMAN, S.M. (1997) Genomic imprinting in mammals. Annu Rev Genet 31:493-525.

BELLVÉ, A.R., CAVICCHIA, J.C., MILLETTE, C.F., O'BRIEN, D.A., BHATNAGAR, Y.M. AND DYM, M. (1977) Spermatogenic cells of the prepuberal mouse.
Isolation and morphological characterisation. J Cell Bio/74:68-85.

BRANDEIS, M., KAFRI, T., ARIEL, M., CHAILLET, J.R., MCCARREY, J., RAZIN, A. and CEDAR, H. (1993) The ontogeny of allele-specific methylation associated with imprinted genes in the mouse. EMBO J12:3669-3677.

BRANNAN, C.I., DEES, E.C., INGRAM, R.S. and TILGHMAN, S.M. (1990) The product of the $\mathrm{H} 19$ gene may function as RNA. Mol Cel/ Bio/10:28-36.

CONSTANCIA, M., PICKARD, B., KELSEY, G. and REIK, W. (1998) Imprinting mechanisms. Genome Res 8:881-900.

DA ROCHA, S.T. and FERGUSON-SMITH, A.C. (2004) Genomic imprinting. Curr Biol. 14:R646-9.

DAVIS, T.L., TRASLER, J.M., MOSS, S.B., YANG, G.J. AND BARTOLOMEI, M.S. (1999) Acquisition of the H19imprint occurs differentially on the parental alleles during spermatogenesis. Genomics 58:18-28.

DAVIS, T.L., YANG, G.J., MCCARREY, J.R. AND BARTOLOMEI, M.S. (2000) The $H 19$ methylation imprint is erased and re-established differentially on the paternal alleles during male germ cell development. Hum Mol Genet 9:28852894.

DELAVAL, K. and FEIL, R. (2004) Epigenetic regulation of mammalian genomic imprinting. Current Opinion in Genetics \& Development 14: 188-195.

DELAVAL, K., GOVIN, J., CERQUEIRA, F., ROUSSEAUX, S., KHOCHBIN, S., FEIL, R. (2007) Differential histone modifications mark mouse imprinting control regions during spermatogenesis. EMBO J26:720-729.

DREWELL, R.A., GODDARD, C.J., THOMAS, J.O. and SURANI, M.A. (2002) Methylation-dependent silencing at the H19imprinting control region by MeCP2. Nucleic Acids Res 30:1139-1144.

DURCOVA-HILLS, G., BURGOYNE, P. and MCLAREN, A. (2004) Analysis of sex differences in EGC imprinting. Developmental Biology 268: 105-110.

EL-MAARRI, O., BUITING, K., PEERY, E.G., KROISEL, P.M., BALABAN, B., WAGNER, K., URMAN, B., HEYD, J., LICH, C., BRANNAN, C.I., WALTER, J. and HORSTHEMKE, B. (2001) Maternal methylation imprints on human chromosome 15 are established during or after fertilization. Nature Genet 27:341344.

FEIL, R., HANDEL, M.A., ALLEN, N.D. and REIK, W. (1995) Chromatin structure and imprinting: developmental control of DNase-I sensitivity in the mouse insulin-like growth factor 2 gene. Dev Genet 17:240-252.

FEIL, R., BOYANO, M.D., ALLEN, N.D. and KELSEY, G. (1997) Parental chromosome-specific chromatin conformation in the imprinted U2af1-rs1 gene in the mouse. J Biol Chem 272:20893-20900.

FEIL, R. and KHOSLA, S. (1999) Genomic imprinting in mammals: an interplay between chromatin and DNA methylation?. Trends Genet 15:431-435.

FERGUSON-SMITH, A.C. and SURANI, M.A. (2001) Imprinting and the epigenetic asymmetry between parental genomes. Science 293:1086-1089.

GREGORY, R.I., O'NEILL, L.P., RANDALL, T.E., FOURNIER, C., KHOSLA, S., TURNER, B.M. and FEIL, R. (2002) Inhibition of histone deacetylase alters allelic chromatin conformation at the imprinted U2af1-rs1 locus in mouse embryonic stem cells. J Biol Chem 277:11728-11734.

HAJKOVA, P., ERHARDT, S., LANE, N., HAAF, T., EL-MAARRI, O., REIK, W., WALTER, J. and SURANI, M.A. (2002) Epigenetic reprogramming in mouse primordial germ cells. Mech Dev117:15-23.

HAJKOVA, P., ANCELIN, K., WALDMANN, T., LACOSTE, N., LANGE, U.C., CESARI, F., LEE, C., ALMOUZNI, G., SCHNEIDER, R., SURANI, M.A. (2008) Chromatin dynamics during epigenetic reprogramming in the mouse germ line. Nature 452:877-881.

HARK, A.T. and TILGHMAN, S.M. (1998) Chromatin conformation of the H19 epigenetic mark. Hum Mol Genet 7:1979-1985.

HATADA, I., SUGAMA, T. and MUKAI, T. (1993) A new imprinted gene cloned by a methylation-sensitive genome scanning method. Nuclei Acids Res 21:55775582.

HAYASHIZAKI, Y., SHIBATA, H., HIROTSUNE, S., SUGINO, H., OKAZAKI, Y., SASAKI, N., HIROSE, K., IMOTO, H., OKUIZUMI, H., MURAMATSU, M., ET $A L$. (1994) Identification of an imprinted U2af binding protein related sequence on mouse chromosome 11 using the RLGS method. Nature Genet6:33-39.

JAENISCH, R. and BIRD, A. (2003) Epigenetic regulation of gene expression: how the genome integrates intrinsic and environmental signals. Nat Genet 33 Suppl:245-54. 
JEONG, Y.S., YEO, S., PARK, J.S., KOO, D.B., CHANG, W.K., LEE, K.K., KANG, Y.K. (2007) DNA methylation state is preserved in the sperm-derived pronucleus of the pig zygote. Int J Dev Bio/51:707-714.

KHOSLA, S., AITCHISON, A., GREGORY, R., ALLEN, N.D. and FEIL, R. (1999) Parental allele-specific chromatin configuration in a boundary/imprinting-control element upstream of the mouse H19 gene. Mol Cell Biol 19:2556-2566.

LI, J.Y., LEES-MURDOCK, D.J., XU, G.L. and WALSH, C.P. (2004) Timing of establishment of paternal methylation imprints in the mouse. Genomics 84:952960.

MAYER, W., NIVELEAU, A., WALTER, J., FUNDELE, R. and HAAF, T. (2000) Demethylation of zygotic paternal genome. Nature 403:501-502.

MURRELL, A. (2006) Genomic imprinting and cancer: from primordial germ cells to somatic cells. TSW Development \& Embryology 1:74-86.

OBATA, Y. and KONO, T. (2002) Maternal primary imprinting is established at a specific time for each gene throughout oocyte growth. J Bio Chem 277:52855289.

OSWALD, J., ENGEMANN, S., LANE, N., MAYER, W., OLEK, A., FUNDELE, R., DEAN, W., REIK, W. and WALTER, J. (2000) Active demethylation of the paternal genome in the mouse zygote. Curr Biol10:475-478.

PACHNIS, V., BRANNAN, C.I. and TILGHMAN, S.M. (1998) The structure and expression of a novel gene activated in early mouse embryogenesis. $E M B O J$ 7:673-681.

PETERS, J. and BEECHEY, C. (2004) Identification and characterisation of imprinted genes in the mouse. Brief Funct Genomic Proteomic 2:320-33.

POLANSKI, Z., MOTOSUGI, N., TSURUMI, C., HIIRAGI, T., HOFFMANN, S. (2008) Hypomethylation of paternal DNA in the late mouse zygote is not essential for development. Int J Dev Bio/52:295-298.

REIK, W. and WALTER, J. (2001a) Genomic imprinting: parental influence on the genome. Nat Rev Genet 2:21-32.

REIK, W. and WALTER, J. (2001b) Evolution of imprinting mechanisms: the battle of the sexes begins in the zygote. Nature Genet 27:255-256.
SANTOS, F., HENDRICH, B., REIK, W. and DEAN, W. (2002) Dynamic reprogramming of DNA methylation in the early mouse embryo. Dev Bio/241:172-182.

SHIBATA, H., YOSHINO, K., SUNAHARA, S., GONDO, Y., KATSUKI, M., UEDA, T., KAMIYA, M., MURAMATSU, M., MURAKAMI, Y., KALCHEVA, I., PLASS, C., CHAPMAN, V.M. and HAYASHIZAKI, Y. (1996) Inactive allele-specific methylation and chromatin structure of the imprinted gene U2af1-rs 1 on chromosome 11. Genomics 35:248-252.

STEWART, C.L., GADI, I. and BHATT, H. (1994) Stem cells from primordial germ cells can reenter the germ line. Dev Bio/ 161: 626-628.

TADA, T., TADA, M., HILTON, K., BARTON, S.C., SADO, T., TAKAGI, N. and SURANI, M.A. (1998) Epigenotype switching of imprintable loci in embryonic germ cells. Dev Genes Evo/207: 551-61.

THORVALDSEN, J.L., MANN, M.R.W., NWOKO, O., DURAN, K.L. and BARTOLOMEI, M.S. (2002) Analysis of sequence upstream of the endogenous H19 gene reveals elements both essential and dispensable for imprinting. Mol Cell Biol22:2450-2462.

TILGHMAN, S.M. (1999) The sins of the fathers and the mothers: Genomic imprinting in mammalian development. Cel/96:185-193.

TRASLER, J.M. (2006) Gamete imprinting: setting epigenetic patterns for the next generation. Reprod Fertil Dev 18:63-69.

TURNER, B.M. (2000) Histone acetylation and an epigenetic code. Bioessays 22:836-845.

UEDA, T., ABE, K., MIURA, A., YUZURIHA, M., ZUBAIR, M., NOGUCHI, M., NIWA, K., KAWASE, Y., KONO, T., MATSUDA, Y., FUJIMOTO, H., SHIBATA, H., HAYASHIZAKI, Y. and SASAKI, H. (2000) The paternal methylation imprint of the mouse $\mathrm{H} 19$ locus is acquired in the gonocyte stage during fetal testis development. Genes Cells 5:649-659.

ZHANG, Z., JOH, K., YATSUKI, H., WANG, Y., ARAI, Y., SOEJIMA, H., HIGASHIMOTO, K., IWASAKA, T., MUKAI, T. (2006) Comparative analyses of genomic imprinting and $\mathrm{CpG}$ island-methylation in mouse Murr1 and human MURR1 loci revealed a putative imprinting control region in mice. Gene 366:7786. 


\section{Further Related Reading, published previously in the Int. J. Dev. Biol.}

See our Special Issue Fertilization in honor of David Garbers and edited by P.M. Wassarman and V.D. Vacquier at: http://www.ijdb.ehu.es/web/contents.php?vol=52\&issue=5/6

See our Special Issue Developmental Biology in Poland edited by Tarkowski, Maleszewski and Kloc at: http://www.ijdb.ehu.es/web/contents.php?vol=52\&issue=2-3

Inadvertent presence of pluripotent cells in monolayers derived from differentiated embryoid bodies Miguel A. Ramírez, Eva Pericuesta, Raúl Fernández-González, Belén Pintado and Alfonso Gutiérrez-Adán Int. J. Dev. Biol. (2007) 51: 397-408

Dynamic distribution of the replacement histone variant $\mathrm{H} 3.3$ in the mouse oocyte and preimplantation embryos Maria-Elena Torres-Padilla, Andrew J. Bannister, Paul J. Hurd, Tony Kouzarides and Magdalena Zernicka-Goetz Int. J. Dev. Biol. (2006) 50: 455-461

A hypothesis linking low folate intake to neural tube defects due to failure of post-translation methylations of the cytoskeleton

Natalie K. Björklund and Richard Gordon

Int. J. Dev. Biol. (2006) 50: 135-141

Control of reproduction by Polycomb Group complexes in animals and plants

Anne-Elisabeth Guitton and Frederic Berger

Int. J. Dev. Biol. (2005) 49: 707-716

Histone methylation defines epigenetic asymmetry in the mouse zygote.

Katharine L Arney, Siqin Bao, Andrew J Bannister, Tony Kouzarides and M Azim Surani

Int. J. Dev. Biol. (2002) 46: 317-320

The expression of the imprinted gene Ipl is restricted to extra-embryonic tissues and embryonic lateral mesoderm during early mouse development.

Sally L Dunwoodie and Rosa S P Beddington

Int. J. Dev. Biol. (2002) 46: 459-466

Methylation and chromatin conformation in the U2af1-rs1 imprinted gene in the male germ cell line

MM Zalduendo, D Boyano, R Feil, N Andollo, J Arechaga

Int. J. Dev. Biol. (2001) 45: S145-S146

Epigenetic reprogramming of the genome-from the germ line to the embryo and back again.

$\mathrm{K} L$ Arney, S Erhardt, R A Drewell and M A Surani

Int. J. Dev. Biol. (2001) 45: 533-540

Igf2 imprinting in development and disease.

W Reik, M Constancia, W Dean, K Davies, L Bowden, A Murrell, R Feil, J Walter and G Kelsey

Int. J. Dev. Biol. (2000) 44: 145-150

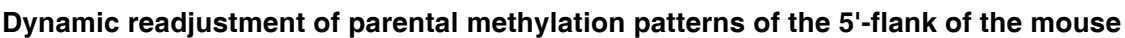
$\mathrm{H} 19$ gene during in vitro organogenesis.

L Liang, C Kanduri, M Pilartz, K Svensson, J H Song, P Wentzel, U Eriksson and R Ohlsson

Int. J. Dev. Biol. (2000) 44: 785-790

2006 ISI **Impact Factor $=3.577^{* *}$

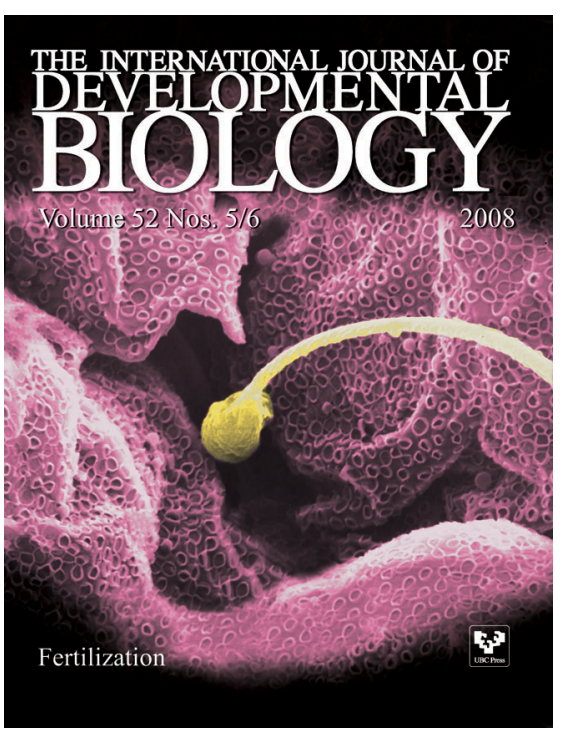

